\title{
Quality Assessment of English Teaching at the Newly Established Universities in Saudi Arabia: Shaqra University as a Case Study
}

\author{
Hmoud S. Alotaibi \\ English Language Department, Shaqra University, KSA
}

\begin{abstract}
As the case world-wide, the English language is central in Saudi schools and universities. Despite its prominence, students' level of English language proficiency is generally believed to be unsatisfactory. This study explores this issue by investigating the quality of teaching with reference to the extent to which professors do employ the course assessment methods of learning domains specified in the course specifications template, provided by the National Commission for Academic Accreditation and Assessment in Saudi Arabia, as one of the main factors for improving teaching processes. To this end, 12 courses in the English BA program at Shaqra university, a newly established university in Saudi Arabia, were investigated. The results have shown a significant problem in the quality of teaching English language. First, the learning domains, i.e. Knowledge, Cognitive Skills, Interpersonal Skills, were barely seen in the exam papers. Second, the methods of assessments specified in the course specifications were moderately used by instructors. The study closes with some suggestions for future investigations.
\end{abstract}

Index Terms-ELT, quality, methods of assessment, learning outcomes

\section{INTRODUCTION}

Higher education in Saudi Arabia has witnessed considerable development over the last years in both quality and quantity to cope with world economic changes and globalization (Elyas, 2008). The objectives of the new educational policy are threefold: (1) to provide all citizens with educational opportunities and advantages, (2) to raise the quality of teaching/learning and (3) to boost the teaching of foreign languages (Hamdan, 2005). Undergraduate programs in the English departments at Saudi universities offer courses in linguistics and literature in addition to some other general courses. Yet, studies conducted over the last decade in the Saudi context have revealed that English graduates from these programs have limited command of English language (Al-Seghayer, 2011).Indeed, the Ministry of Educationin Saudi Arabia has been complaining about the plummeting levels of English language competence of English teachers, which can be manifested by the failure records inthe English Language Entrance Proficiency Test given to candidates applying to teach English at the Ministry of Education. Al-Seghayer (2011) noted that according to the Educational Testing Services (ETS) reports from 2003 to 2009, "Saudi students who took the Test of English as a Foreign language (TOEFL) scored the lowest among Middle Eastern and Asian college students" (p. 82). It is both interesting and alarming to note that the low level of English language proficiency among Saudi students is found even among graduates holding a Bachelor's degree in English. This has motivated language researchers to investigate the contributing factors to this phenomenon. In recent years, there has been a massive expansion in higher education institutions in Saudi Arabia, the fact that necessitates conducting more studies to help in designing appropriate methodologies for teaching the English languagethat suit these new environments. Indeed, the twelve newly established universities, along with other colleges in small towns and villages, require immediate evaluation of the current methodologies of ELT. Some students acknowledge their low proficiency and choose to take intensive English courses abroad upon their graduation. Moreover, the newly graduates of English are not only unable to work for the Ministry of Education, but also they might face difficulties working in companies and sectors that require good command of English language. Hence, the present study's problem stems from the need to investigate and address this serious issue. The study aims to explore the main causes of the low proficiency of English among university students by evaluating the quality of teaching English language based on the templates provided by the National Commission for Academic Accreditation and Assessment in Saudi Arabia.

Previous studies onstudents' low proficiency of English languageat newly established universities have focused on the four language skills, namely writing (e.g. Al-Khairy, 2013; Jahin \& Idrees, 2012; Salebi, 2004), speaking (e.g. Baniabdelrahman, 2013), listening (e.g. Al-Enazi, 2010), and the integration of reading and writing (e.g. Aldosari, 2011). While these studies are important in the field of ELT to address the four language skills in Saudi institutions, there is still an important area that has not been addressed so far; that is the quality of teaching English language. Thus, this study examines the extent to which English language professors at Shaqra university, as a newly established university, adhere to the course specifications developed by the National Commission for Academic Accreditation and 
Assessment in Saudi Arabia.The mission of this Commission, according to the manual published in the Commission's website, has been described as:

The National Commission for Academic Accreditation \& Assessment (NCAAA) has been established in the Kingdom of Saudi Arabia with responsibility for determining standards and criteria for academic accreditation and assessment and for accrediting postsecondary institutions and the programs they offer. The Commission is committed to a strategy of encouraging, supporting, and evaluating the quality assurance processes of postsecondary institutions to ensure that quality of learning and management of institutions are equivalent to the highest international standards. (p. 3).

The Commission has developed several templates to provide a clear guidance for procedures to be followed. The course specifications template in particular has been designed "so those who are to teach the course are clear about what is to be learned, what its contributions are to the overall program, and how its effectiveness should be assessed" (p. 32). The manual also maintained that

Individual course specifications must be prepared for each course in a program, and kept on file with the program specifications. The purpose is to make clear the details of planning for the course as part of the package of arrangements to achieve the intended learning outcomes of the program as a whole. Consequently, course specifications include the knowledge and skills to be developed in keeping with the NQF[National Qualifications Framework] and the overall learning outcomes of the program, the strategies for teaching and assessment in sufficient detail to guide individual instructors. Course learning outcomes, teaching strategies, and teaching methods are to be in alignment. (p. 34).

Therefore, the present study seeks to investigate the course specifications of 12 English courses in the English BA programs at Shaqra university. Two areas in each course specifications template will be examined:

1- NQF Learning Domains and Course Learning Outcomes.

A- Knowledge

B- Cognitive Skills

C- Interpersonal Skills

2- Course Assessment Methods

Specifically, the study seeks to answer the following research questions:

a) Have the methods of course assessment, indicated in the "course specification" templates, been used in teaching the selected 12 courses?.

b) Is there any variation with respect to the employment of the three learning domains (i.e. knowledge, cognitive skills, and interpersonal skills)?

c) In the light of the two previous questions, does the gender of the instructor play any role?

\section{METHODOLOGY}

The data comprise the course specification of 12 coursesin the BA English program at Shaqra university, a newly established university in Saudi Arabia. The courses are chosen because they cover the basic language skills, namely reading, writing, listening, and speaking, in addition to grammar. The courses are the following:

ENG 111 (Basic Language Skills),

ENG 112 (Listening and Speaking-1),

ENG 113 (Reading Comprehension -1),

ENG 114 (Composition-1),

ENG 115 (Reading Comprehension-2),

ENG 116 (Grammar),

ENG 120 (Vocabulary Building),

ENG 122 (Listening and Speaking-2),

ENG 213 (Composition-2),

ENG 312 (Essay Writing),

ENG 412 (Speech), and

ENG 413 (Advanced Writing).

The course specification template is designed by the National Commission for Academic Accreditation and Assessment in Saudi Arabia, yet teachers have to supply the content. The Deanship of Quality and Development at Shaqra university has managed to unify the content of course specifications in all similar academic programs. Shaqra University has six English departments distributed in six colleges, but the course specification of each academic course is only one which is approved by the Deanship of Quality and Development.

The course specification of each course was retrieved and two sections, i.e. a) NQF Learning Domains and Course Learning Outcomes (Knowledge, Cognitive Skills, Interpersonal Skills), b) Course Assessment Methods were investigated.In the cases where the assessment methods indicated "exam," whether final or mid-term, the exam sheets were collected from the instructors. In the cases where the assessment methods could not be verified by the researcher, a questionnaire was designed to inquire about the employment of the assessment methods that have been indicated in the course specifications.In the questionnaire and due to space constrains, we report the responses (Yes/No) to the employment of the methods of assessment. In the analysis of the exam papers, however, we provide full account of the 
employment of the learning domains (Knowledge, Cognitive skills and Interpersonal skills). A total of 25 instructors filled in the questionnaire. For each course, however, the questionnaire gave a chance to skip the question if the instructor did not teach the course; thus the number of instructors varied in each course.

\section{RESUlts}

\section{A. The Employment of the Learning Domains in the Exam Papers}

This part covers the investigation of using the three learning domains, i.e. knowledge, cognitive skills, and interpersonal skills, in the two mid-term and final exams according to what has been indicated in the course specifications. The papers of exams were collected, and for each course, one package of exams from male instructors was selected and similarly one package from the female group was selected for thorough review. Tables 1,2 , and 3 present the findings of the analysis of using learning domains in the $1^{\text {st }}$ Mid-term exam, $2^{\text {nd }}$ Mid-term exam, and final exam, respectively.

TABLE 1.

THE EMPLOYMENT OF THE LEARNING DOMAINS IN THE $1^{\text {ST }}$ MID-TERMEXAM

\begin{tabular}{|c|c|c|c|c|c|c|c|c|c|}
\hline \multirow[t]{3}{*}{$1^{\text {st }} \mathrm{Mid}$} & \multicolumn{3}{|c|}{ Knowledge } & \multicolumn{3}{|l|}{ Cognitive } & \multicolumn{3}{|c|}{ Interpersonal } \\
\hline & \multirow{2}{*}{$\begin{array}{l}\text { Indicated } \\
\mathrm{M} / \mathrm{F}\end{array}$} & \multicolumn{2}{|c|}{ Employed } & \multirow{2}{*}{$\begin{array}{l}\text { Indicated } \\
\mathrm{M} / \mathrm{F}\end{array}$} & \multicolumn{2}{|c|}{ Employed } & \multirow{2}{*}{$\begin{array}{l}\text { Indicated } \\
\mathrm{M} / \mathrm{F}\end{array}$} & \multicolumn{2}{|c|}{ Employed } \\
\hline & & Male & Female & & Male & Female & & Male & Female \\
\hline ENG 111 & 3 & 3 & 3 & 4 & 2 & 1 & 3 & 1 & 1 \\
\hline ENG 112 & 2 & 2 & 1 & 4 & 2 & 0 & 5 & 2 & 2 \\
\hline ENG 113 & 1 & 0 & 1 & 2 & 0 & 1 & 2 & 0 & 1 \\
\hline ENG 114 & 4 & 2 & 2 & 6 & 1 & 0 & 4 & 3 & 2 \\
\hline ENG 115 & 5 & 2 & 2 & 2 & 0 & 0 & 3 & 1 & 1 \\
\hline ENG 116 & 3 & 1 & 3 & 3 & 1 & 1 & 3 & 1 & 1 \\
\hline ENG 120 & 3 & 1 & 1 & 2 & 1 & 1 & 3 & 1 & 1 \\
\hline ENG 122 & 4 & 1 & 2 & 3 & 0 & 0 & 6 & 1 & 1 \\
\hline ENG 213 & 4 & 1 & 1 & 3 & 1 & 2 & 3 & 0 & 0 \\
\hline ENG 312 & 5 & 1 & 0 & 4 & 1 & 3 & 4 & 1 & 1 \\
\hline ENG 412 & 3 & 0 & 2 & 4 & 1 & 1 & 4 & 0 & 0 \\
\hline ENG 413 & 4 & 2 & 2 & 4 & 3 & 1 & 4 & 1 & 1 \\
\hline Average & 3.4 & 1.3 & 1.6 & 3.4 & 1.08 & 0.9 & 3.6 & 1 & 1 \\
\hline $\mathrm{x}^{2}$-value & & 14.267 & 12.133 & & 16.200 & 18.000 & & 18.667 & 21.333 \\
\hline Sig & & $.014^{*}$ & $.033 *$ & & $.006^{*}$ & $.003 *$ & & $.005 *$ & $.002 *$ \\
\hline
\end{tabular}

TABLE 2.

THE EMPLOYMENT OF THE LEARNING DOMAINS IN THE $2^{\text {ND }}$ MID-TERM

\begin{tabular}{|c|c|c|c|c|c|c|c|c|c|}
\hline \multirow[t]{3}{*}{$2^{\text {nd }} \mathrm{Mid}$} & \multicolumn{3}{|c|}{ Knowledge } & \multicolumn{3}{|l|}{ Cognitive } & \multicolumn{3}{|c|}{ Interpersonal } \\
\hline & \multirow{2}{*}{$\begin{array}{l}\text { Indicated } \\
\mathrm{M} / \mathrm{F}\end{array}$} & \multicolumn{2}{|c|}{ Employed } & \multirow{2}{*}{$\begin{array}{l}\text { Indicated } \\
\mathrm{M} / \mathrm{F}\end{array}$} & \multicolumn{2}{|c|}{ Employed } & \multirow{2}{*}{$\begin{array}{l}\text { Indicated } \\
\mathrm{M} / \mathrm{F}\end{array}$} & \multicolumn{2}{|c|}{ Employed } \\
\hline & & Male & Female & & Male & Female & & Male & Female \\
\hline ENG 111 & 3 & 3 & 3 & 4 & 2 & 1 & 3 & 1 & 1 \\
\hline ENG 112 & 2 & 0 & 1 & 4 & 2 & 0 & 5 & 2 & 2 \\
\hline ENG 113 & 1 & 1 & 0 & 2 & 0 & 0 & 2 & 1 & 0 \\
\hline ENG 114 & 4 & 2 & 1 & 6 & 1 & 0 & 4 & 3 & 2 \\
\hline ENG 115 & 5 & 1 & 2 & 2 & 0 & 0 & 3 & 1 & 1 \\
\hline ENG 116 & 3 & 1 & 1 & 3 & 1 & 1 & 3 & 1 & 1 \\
\hline ENG 120 & 3 & 1 & 1 & 2 & 1 & 1 & 3 & 1 & 1 \\
\hline ENG 122 & 4 & 1 & 2 & 3 & 0 & 0 & 6 & 1 & 1 \\
\hline ENG 213 & 4 & 1 & 1 & 3 & 1 & 1 & 3 & 0 & 0 \\
\hline ENG 312 & 5 & 1 & 0 & 4 & 1 & 3 & 4 & 1 & 1 \\
\hline ENG 412 & 3 & 0 & 2 & 4 & 1 & 1 & 4 & 0 & 0 \\
\hline ENG 413 & 4 & 2 & 1 & 4 & 3 & 1 & 4 & 1 & 1 \\
\hline Average & 3.4 & 1.16 & 1.25 & 3.4 & 1.08 & 0.75 & 3.6 & 1.08 & 0.91 \\
\hline $\mathrm{x}^{2}$-value & & 9.943 & 9.943 & & 24.000 & 24.000 & & 21.000 & 21.000 \\
\hline Sig & & .127 & .127 & & $.001 *$ & $.001 *$ & & $.001 *$ & $.001 *$ \\
\hline
\end{tabular}


TABLE 3.

THE EMPLOYMENT OF THE LEARNING DOMAINS IN THE FINAL EXAM

\begin{tabular}{|c|c|c|c|c|c|c|c|c|c|}
\hline \multirow[t]{3}{*}{ Final } & \multicolumn{3}{|c|}{ Knowledge } & \multicolumn{3}{|l|}{ Cognitive } & \multicolumn{3}{|c|}{ Interpersonal } \\
\hline & \multirow{2}{*}{$\begin{array}{l}\text { Indicated } \\
\mathrm{M} / \mathrm{F}\end{array}$} & \multicolumn{2}{|c|}{ Employed } & \multirow{2}{*}{$\begin{array}{l}\text { Indicated } \\
\mathrm{M} / \mathrm{F}\end{array}$} & \multicolumn{2}{|c|}{ Employed } & \multirow{2}{*}{$\begin{array}{l}\text { Indicated } \\
\mathrm{M} / \mathrm{F}\end{array}$} & \multicolumn{2}{|c|}{ Employed } \\
\hline & & Male & Female & & Male & Female & & Male & Female \\
\hline ENG 111 & 3 & 2 & 3 & 4 & 2 & 1 & 3 & 1 & 1 \\
\hline ENG 112 & 2 & 0 & 1 & 4 & 2 & 0 & 5 & 2 & 2 \\
\hline ENG 113 & 1 & 1 & 1 & 2 & 0 & 2 & 2 & 1 & 1 \\
\hline ENG 114 & 4 & 2 & 2 & 6 & 4 & 1 & 4 & 3 & 2 \\
\hline ENG 115 & 5 & 1 & 2 & 2 & 0 & 0 & 3 & 1 & 1 \\
\hline ENG 116 & 3 & 2 & 3 & 3 & 1 & 1 & 3 & 1 & 1 \\
\hline ENG 120 & 3 & 1 & 2 & 2 & 1 & 1 & 3 & 1 & 1 \\
\hline ENG 122 & 4 & 0 & 2 & 3 & 0 & 0 & 6 & 1 & 1 \\
\hline ENG 213 & 4 & 2 & 2 & 3 & 1 & 2 & 3 & 0 & 0 \\
\hline ENG 312 & 5 & 2 & 0 & 4 & 1 & 3 & 4 & 1 & 1 \\
\hline ENG 412 & 3 & 0 & 0 & 4 & 0 & 0 & 4 & 0 & 0 \\
\hline ENG 413 & 4 & 2 & 2 & 4 & 3 & 1 & 4 & 1 & 1 \\
\hline Average & 3.4 & 1.25 & 1.6 & 3.4 & 1.25 & 1 & 3.6 & 1.08 & 1 \\
\hline $\mathrm{x}^{2}$-value & & 7.633 & 11.048 & & 21.333 & 15.700 & & 21.000 & 21.000 \\
\hline Sig & & .266 & .087 & & $.002 *$ & $.015^{*}$ & & $.001 *$ & $.001 *$ \\
\hline
\end{tabular}

The results indicate an evident gap between what has been indicated in the course specifications and what has actually been assessed. For the knowledge skills, we see that there are 3.4 items that are indicated in the course specifications which should be assessed through mid-term and final exams. However, we see that the instructors, male and females, have assessed between 1.16- 1.6 items with a slight rise in the female group. The investigation of employing the Cognitive skills shows the same problem, as what has been indicated in the course specifications is an average of 3.4 items while what has been actually assessed in the exam sheets ranges from 0.75 to 1.25 . A very interesting gender difference is noted as male instructors do better in assessing Cognitive skills throughout the three exam types. The assessment of Interpersonal Skills in the exam papers is the least among the three learning domains, as there are 3.6 items indicated in the course specifications but an average of 0.9 to 1.08 are assessed. Again, male instructors do better in assessing Interpersonal Skills according to the second-midterm and finale exam papers. Chisquare test has been performed to see whether the previous results are statistically significant. All previous results are found to be statistically significant except for those of Knowledge domain in second-mid-term and final exam paper.

\section{B. The Employment of the Methods of Assessment}

This section reports the findings regarding whether the methods of assessment are actually used by instructors according to what are indicated in the course specifications. In some courses, the course specifications do not indicate any method of assessment and consequently these are not included in the questionnaire. Instructors are asked to choose Yes or No for each item (i.e. method of assessment) in order to verify that they actually use the methods of assessment. Table 4 summarizes the overall results of the employment the methods of assessments that have been indicated in the course specifications. Table 5 focuses on the male group, and Table 6 reports the responses indicated by female instructors.

TABLE 4.

THE RESPONSES REGARDING USING THE METHODS OF ASSESSMENT

\begin{tabular}{|c|c|c|c|c|c|c|c|c|c|c|c|c|}
\hline Method & \multicolumn{2}{|c|}{ Class Participation } & \multicolumn{2}{|c|}{ Quizzes } & \multicolumn{2}{|c|}{ Pair Work } & \multicolumn{2}{|c|}{ Home Assignment } & \multicolumn{2}{|c|}{ Oral Presentation } & \multicolumn{2}{|c|}{ Project } \\
\hline $\begin{array}{l}\text { Yes/No } \\
\%\end{array}$ & $\begin{array}{l}\text { Yes } \\
\%\end{array}$ & $\begin{array}{l}\text { No } \\
\%\end{array}$ & $\begin{array}{l}\text { Yes } \\
\%\end{array}$ & $\begin{array}{l}\text { No } \\
\%\end{array}$ & $\begin{array}{l}\text { Yes } \\
\%\end{array}$ & $\begin{array}{l}\text { No } \\
\%\end{array}$ & $\begin{array}{l}\text { Yes } \\
\%\end{array}$ & $\begin{array}{l}\text { No } \\
\%\end{array}$ & $\begin{array}{l}\text { Yes } \\
\%\end{array}$ & $\begin{array}{l}\text { No } \\
\%\end{array}$ & $\begin{array}{l}\text { Yes } \\
\%\end{array}$ & $\begin{array}{l}\text { No } \\
\%\end{array}$ \\
\hline ENG 111 & 63.6 & 36.4 & 80 & 20 & 60 & 40 & 60 & 40 & & & & \\
\hline ENG 112 & 87.5 & 12.5 & 66.7 & 33.3 & 87.5 & 12.5 & & & 81.3 & 18.8 & & \\
\hline ENG 113 & 92.3 & 7.7 & 76.9 & 23.1 & 61.5 & 38.5 & & & & & & \\
\hline ENG 114 & 76.9 & 23.1 & 66.7 & 33.3 & 50 & 50 & 66.7 & 33.3 & & & & \\
\hline ENG 115 & 90.9 & 9.1 & 70 & 30 & & & 81.8 & 18.2 & & & 45.5 & 54.5 \\
\hline ENG 116 & 80 & 20 & 60 & 40 & 40 & 60 & 70 & 30 & & & & \\
\hline ENG 120 & 90.9 & 9.1 & 81.8 & 18.2 & & & 83.3 & 16.7 & 18.2 & 81.8 & 18.2 & 81.8 \\
\hline ENG 122 & 91.7 & 8.3 & & & 72.7 & 27.3 & & & 75 & 25 & & \\
\hline ENG 213 & 87.5 & 12.5 & 85.7 & 14.3 & & & 88.9 & 11.1 & & & & \\
\hline ENG 312 & 100 & 0 & 77.8 & 22.2 & & & 87.5 & 12.5 & & & 57.1 & 42.9 \\
\hline ENG 412 & & & & & & & & & 80 & 20 & & \\
\hline ENG 413 & 100 & 0 & & & 71.4 & 28.6 & & & 42.9 & 57.1 & 100 & 0 \\
\hline Average & 87.4 & 12.6 & 74 & 26 & 63.3 & 36.7 & 76.9 & 23.1 & 59.5 & 40.5 & 55.2 & 44.8 \\
\hline
\end{tabular}


TABLE 5.

THE RESPONSES REGARDING USING THE METHODS OF ASSESSMENT BY MALE INSTRUCTORS

\begin{tabular}{|c|c|c|c|c|c|c|c|c|c|c|c|c|}
\hline \multirow{2}{*}{$\begin{array}{l}\text { Male } \\
\text { Yes/No } \\
\%\end{array}$} & \multicolumn{2}{|c|}{ Class Participation } & \multicolumn{2}{|c|}{ Quizzes } & \multicolumn{2}{|c|}{ Pair Work } & \multicolumn{2}{|c|}{ Home Assignment } & \multicolumn{2}{|c|}{ Oral Presentation } & \multicolumn{2}{|c|}{ Project } \\
\hline & $\begin{array}{l}\text { Yes } \\
\%\end{array}$ & $\begin{array}{l}\text { No } \\
\%\end{array}$ & $\begin{array}{l}\text { Yes } \\
\%\end{array}$ & $\begin{array}{l}\text { No } \\
\%\end{array}$ & $\begin{array}{l}\text { Yes } \\
\%\end{array}$ & $\begin{array}{l}\text { No } \\
\%\end{array}$ & $\begin{array}{l}\text { Yes } \\
\%\end{array}$ & $\begin{array}{l}\text { No } \\
\%\end{array}$ & $\begin{array}{l}\text { Yes } \\
\%\end{array}$ & $\begin{array}{l}\text { No } \\
\%\end{array}$ & $\begin{array}{l}\text { Yes } \\
\%\end{array}$ & $\begin{array}{l}\text { No } \\
\%\end{array}$ \\
\hline ENG 111 & 100 & 0 & 100 & 0 & 66.6 & 33.3 & 66.6 & 33.3 & - & - & - & - \\
\hline ENG 112 & 100 & 0 & 100 & 0 & 80 & 20 & - & - & 80 & 20 & - & - \\
\hline ENG 113 & 100 & 0 & 100 & 0 & 66.6 & 33.3 & - & - & - & - & - & - \\
\hline ENG 114 & 100 & 0 & 66.6 & 33.3 & 66.6 & 33.3 & 100 & 0 & - & - & - & - \\
\hline ENG 115 & 100 & 0 & 100 & 0 & - & - & 100 & 0 & - & - & 66.6 & 33.3 \\
\hline ENG 116 & 100 & 0 & 100 & 0 & 50 & 50 & 100 & 0 & - & - & - & - \\
\hline ENG 120 & 100 & 0 & 75 & 25 & - & - & 100 & 0 & 25 & 75 & 25 & 75 \\
\hline ENG 122 & 100 & 0 & - & - & 75 & 25 & - & - & 50 & 50 & - & - \\
\hline ENG 213 & 75 & 25 & 75 & 25 & - & - & 100 & 0 & - & - & - & - \\
\hline ENG 312 & 100 & 0 & 100 & 0 & - & - & 100 & 0 & - & - & 66.6 & 33.3 \\
\hline ENG 412 & - & - & - & - & - & - & - & - & 60 & 40 & - & - \\
\hline ENG 413 & 100 & 0 & - & - & 66.6 & 33.3 & - & - & 33.3 & 66.6 & 100 & 0 \\
\hline Average & 97.7 & 2.3 & 90.7 & 9.3 & 67.4 & 32.6 & 95.3 & 4.7 & 49.7 & 50.3 & 64.6 & 35.4 \\
\hline
\end{tabular}

TABLE 6.

THE RESPONSES REGARDING USING THE METHODS OF ASSESSMENT BY FEMALE INSTRUCTORS

\begin{tabular}{|c|c|c|c|c|c|c|c|c|c|c|c|c|}
\hline Female & \multicolumn{2}{|c|}{ Class Participation } & \multicolumn{2}{|c|}{ Quizzes } & \multicolumn{2}{|c|}{ Pair Work } & \multicolumn{2}{|c|}{ Home Assignment } & \multicolumn{2}{|c|}{ Oral Presentation } & \multicolumn{2}{|c|}{ Project } \\
\hline $\begin{array}{l}\text { Yes/No } \\
\%\end{array}$ & $\begin{array}{l}\text { Yes } \\
\%\end{array}$ & $\begin{array}{l}\text { No } \\
\%\end{array}$ & $\begin{array}{l}\text { Yes } \\
\%\end{array}$ & $\begin{array}{l}\text { No } \\
\%\end{array}$ & $\begin{array}{l}\text { Yes } \\
\%\end{array}$ & $\begin{array}{l}\text { No } \\
\%\end{array}$ & $\begin{array}{l}\text { Yes } \\
\%\end{array}$ & $\begin{array}{l}\text { No } \\
\%\end{array}$ & $\begin{array}{l}\text { Yes } \\
\%\end{array}$ & $\begin{array}{l}\text { No } \\
\%\end{array}$ & $\begin{array}{l}\text { Yes } \\
\%\end{array}$ & $\begin{array}{l}\text { No } \\
\%\end{array}$ \\
\hline ENG 111 & 75 & 25 & 100 & 0 & 75 & 25 & 50 & 50 & - & - & - & - \\
\hline ENG 112 & 88.9 & 11.1 & 44.4 & 55.6 & 77.8 & 22.2 & - & - & 77.8 & 22.2 & - & - \\
\hline ENG 113 & 87.5 & 12.5 & 50 & 50 & 50 & 50 & - & - & - & - & - & - \\
\hline ENG 114 & 100 & 0 & 66.7 & 33.3 & 50 & 50 & 66.7 & 33.3 & - & - & - & - \\
\hline ENG 115 & 85.7 & 14.3 & 57.2 & 42.8 & - & - & 71.4 & 28.6 & - & - & 28.6 & 71.4 \\
\hline ENG 116 & 83.3 & 16.7 & 50 & 50 & 33.3 & 66.7 & 66.7 & 33.3 & - & - & - & - \\
\hline ENG 120 & 85.7 & 14.3 & 85.7 & 14.3 & - & - & 71.4 & 28.6 & 0 & 100 & 0 & 100 \\
\hline ENG 122 & 100 & 0 & - & - & 83.3 & 16.7 & - & - & 100 & 0 & - & - \\
\hline ENG 213 & 100 & 0 & 100 & 0 & - & - & 100 & 0 & - & - & - & - \\
\hline ENG 312 & 100 & 0 & 60 & 40 & - & - & 60 & 40 & - & - & 20 & 80 \\
\hline ENG 412 & - & - & - & - & - & - & - & - & 100 & 0 & - & - \\
\hline ENG 413 & 100 & 0 & - & - & 66.7 & 33.3 & - & - & 33.3 & 66.7 & 100 & 0 \\
\hline Average & 91.5 & 8.5 & 68.2 & 31.8 & 62.3 & 37.7 & 69.5 & 30.5 & 62.2 & 37.8 & 37.1 & 62.8 \\
\hline
\end{tabular}

It is important to note that the values of assessment methods in some courses in Table 1 (and consequently in Tables 2 and 3) are left blank because there is no indication in the course specifications that they are part of student assessment. It is beyond the scope of this paper to discuss the missing of each method of assessment. The questionnaire follows what has been indicated in the course specifications and verifies whether they are actually used. According to Table 4, we see that the methods of assessments (with varying degrees) were not always used, although they were indicated in the course specifications. Regarding the Class Participation, Table 4 shows that $12.6 \%$ of instructors write it in their course specifications, but actually do not use it. In fact, the percentage of 12.6 is still high as Class Participation is a very common method of assessment. Tables 5 and 6 indicate that there is no clear gender difference in using Class Participation as a method of assessment although the percentage of female instructors who do not apply it is higher than male professors. Concerning the use of Quizzes, Table 4 shows that around a quarter of professors do not use it as a method of assessment. Tables 5 and 6, explain that most female instructors do not use quizzes as a method of assessment. Also, the analysis of Pair Work as a method of assessment reveals a problem in the quality of teaching as $36.7 \%$ of instructors do not employ it to assess the learning domains specified in the course specifications. Tables 5 and 6 discern no significant difference due to gender though the percentage of female instructors who do not use Pair Work as a method of assessment is higher. Likewise, the investigation of using Home Assignments indicates a problem as nearly a quarter $(23.1 \%)$ of instructors have reported that they do not use it as a method of assessment. According to Tables 5 and 6, female instructors are the ones who refrain the most from using this method of assessment. The case of Oral Presentation seems different as it is indicated as a method of assessment in the course specifications of five courses only. In these courses, around $40 \%$ of instructors do not use it as a method of assessment. The percentage of male instructors who do not use it is a slightly higher than that of female instructors. Finally, assigning Projects such as writing research papers is indicated in only 4 courses, and there is around $45 \%$ of professors do not actually use it as a method of assessment with a higher percentage in the female group.

\section{CONCLUSION}

The purpose of the study is to examine the employment of the learning domains (knowledge, cognitive, and interpersonal skills) that are stated in the course specifications of 12 courses in the BA English program at a newly established university in Saudi Arabia. First, the exam papers of these courses are collected and analyzed to verify that the learning domains are assessed in the exams. Second, a questionnaire is given to the instructors of these courses to 
examine to what extent the methods of assessment areused to assess the indicated learning domains. The analysis of the exam papers has yielded striking findings as the learning outcomes specified in the course specifications are scarcely found. Likewise, the instructors' responses to using the methods of assessment, described in the course specifications, are not always positive. For some methods, around $45 \%$ of instructors maintain that they do not use the specified method of assessment as part of their assessment to the learning outcomes. These findings clearly indicate a problem in the quality of teaching the English language as the learning outcomes specified in the course specifications are not taken seriously by instructors. Hence, we argue that overlooking the employment of learning domainsby instructorsmay negatively reflect on students' learning outcomes in the English BA program as a whole and could consequently be added to factors responsible for low level of English proficiency.

Yet, before we make broad generalizations, some limitations of the study need to be addressed. First, the study focuses on two English departments at Shaqra University which has six English departments. Therefore, the results might have been different if the investigation had covered all of the English departments at this university. Secondly, the study has been investigated in only one university, and to have a clearer picture of the extent to which instructors follow the course specifications, more comprehensive research in the future is recommended to include a larger number of universities in Saudi Arabia. Thirdly, due to the space constraints, the analysis of the questionnaire has been restricted to the employment of methods of assessment in generalwithout investigating the learning domains under each method.Thus, futurestudies are advised to make thoroughinvestigations of the course specificationsand also should examine the parts that have not been covered in this study such as the objectives of the course. Despite these limitations, this study is informative and useful for professors and curriculum designers at Shaqra University and other universities in Saudi Arabia as it draws attention to a salient issue related to the quality of teaching the English language.

\section{ACKNOWLEDGEMENTS}

The work reported in this paper was supported by a research grant from the Deanship of Scientific Research at Shaqra University (D170426/G01/N005). The author is grateful for this financial support.

\section{REFERENCES}

[1] Aldosari, H. (2011). Effects of integrating reading and writing during the reading process on EFL English writing in a Saudi college course: a quasi-experimental study. Paper Presented at the First International Forum on Academic Teaching: Social Inclusion and Information and Communication Technology, $3^{\text {rd }}$ to $5^{\text {th }}$ October 2011, Uberlandia, Minas Gerais, Brazil.

[2] Al-Enazi, M. (2010). A Suggested model for developing listening skill for first year English department students at Arar college of education. Unpublished MA thesis. King Abdulaziz University.

[3] Al-Khairy, M. (2013). Saudi English-major undergraduates' academic writing problems: Taif university perspective. English Language Teaching, 6(6): 1-12.

[4] Al-Seghayer, K. (2011). English teaching in Saudi Arabia: Status, issues, and challenges. Hala Print Co. Riyadh, Saudi Arabia.

[5] Baniabdelrahman, A. (2013). Effect of using internet tools on enhancing EFL students' speaking skill. American International Journal of Contemporary Research, 3(6).79-87.

[6] Elyas, T. (2008). The Attitude and the Impact of American English as a Global Language within the Saudi Education System. Novitas-ROYAL: Research on Youth and Language, 2(1): 28-48.

[7] Hamdan, A. (2005). Women education in Saudi Arabia: challenges and achievements. International Education Journal. 6(1), $42-64$.

[8] Jahin, J. \& Idrees, M. (2012). EFL major student teachers' writing proficiency and attitudes towards learning English, Umm AlQura University Journal of Educational \& Psychologic Sciences, 4(1), 9-72.

[9] National Commission for Academic Accreditation \& Assessment Handbook for Quality Assurance and Accreditation Part 2, Version 3, October 2015. (Retrieved from www.ncaaa.org.sa on February 15, 2018).

[10] Salebi, M. (2004). Saudi college students' perception of their errors in written English. Scientific Journal of King Faisal University, 5(2): 209-228.

Hmoud Alotaibi holds a PhD in Written Discourse from Texas A\&M University-Commerce, Texas, USA, and M.A. in English literature from Cleveland State University, Ohio, USA. He works as a dean of graduate studies, and an associate professor of English at Shaqra University, Saudi Arabia. His research interests are genre analysis, academic wiring, and English for academic purposes. 